\title{
Seed Germination and Grain Quality of Rice as Affected by False Smut Disease
}

\author{
B Nessa ${ }^{1,2^{*}}$, S S Dipti², M U Salam³ , A H M M Haque ${ }^{1}$, J K Biswas², \\ M A Kashem ${ }^{4}$ and M S Kabir ${ }^{2}$
}

\begin{abstract}
Rice false smut (RFSm) is a disease of interest globally and in Bangladesh. Its occurrence and spread have drawn attention since 2010 in the country. While many reports are available on the yield loss from the disease, little is known of its effect on grain quality. Besides, there has been no information on how RFSm affects the seed quality with respect to germination. This study attempted evaluation of seed germination and grain quality of rice as affected by false smut disease. Three years' study provided strong indication of inferior milling outturn and head rice yield in RFSm contaminated seeds. Results further revealed reduced amylose content and increased protein content in the contaminated seeds. Tendency in reduced seed germination, and less cooking time was observed in RFSm contaminated seeds. Future research is suggested to fully understand those causations.

Key words: Rice false smut, yield loss, grain quality, seed germination, Ustilaginoidea virens, Villosiclava virens
\end{abstract}

\section{INTRODUCTION}

False smut (RFSm) (anamorph: Ustilaginoidea virens (Cooke) Takah.; teleomorph: Villosiclava virens (Nakata) E. Tanaka \& C. Tanaka) is a disease of interest in today's rice world. Historically it has been treated as minor disease (Webster and Gunnell, 1992) as not causing significant yield loss on a regular basis across wider geographical regions of the world. At present, its traditional status has changed with widespread reports in almost all the rice growing countries of the globe (Nessa et al. 2015; Nessa, 2017). With increasing incidence being reported from farmers' fields since early 2010s, RFSm is now an emerging disease in Bangladesh (Dhaka Tribune, 2013). The adoption of 'BRRI dhan49', a promising genotype for 'T. Aman' season in Bangladesh, is being seriously affected by this disease (Kabir et al., 2015).

RFSm is a unique disease in the sense that symptoms are only visible after flowering, where the fungus infects individual spikelets and replaces the kernel with a large velvety orange or greenish-black ball (Nessa, 2017), commonly known as 'smut ball'. The yield loss from RFSm has been reported in many countries in varying figures ranging from 1 (Atia, 2004) to over 75\% (Upadhyay and Singh, 2013). The density of smut balls can reach as high as 136; there is $\sim 30 \%$ probability that $1, \sim 14 \%$ probability that 2 , $\sim 10 \%$ probability that $3, \sim 7 \%$ probability that 4 and $\sim 6 \%$ probability that 5 smuts balls will form on an infected panicle (Nessa et al., 2016). Sarker et al. (2016) recorded on average $0.72 \%$ yield loss in four surveyed 'unions' of Natore district of Bangladesh; however, in severe cases the loss went up to $4.5 \%$ in few fields. Nessa et al. (2015) found and proved that chaffiness was more influencing than weight reduction in individual grains in explaining yield reduction due to RFSm. In addition to yield loss, the disease can affect the seed germination and grain quality.

\footnotetext{
${ }^{1}$ Department of Plant Pathology and Seed Science, Sylhet Agricultural University, Sylhet 3100, Bangladesh; ${ }^{2}$ Bangladesh Rice Research Institute (BRRI), Gazipur 1701, Bangladesh; and ${ }^{3}$ Freelance Consultant (Agricultural Research, Development and Modelling), C1 (Dishari-10), BRRI Residential Area, BRRI, Gazipur 1701 and ${ }^{4}$ Department of Soil Science, Sylhet Agricultural University, Sylhet 3100. Corresponding author's E-mail: runu.brri@yahoo.com
} 
Characteristically, RFSm pathogen produces mycotoxins (Zhang et al., 2014). Those toxins can inhibit seed germination (Abbas et al., 2000). A number of studies have observed decrease in seed germination with RFSm contaminated seeds (Hu, 1985; Hegde and Anahosur, 2000; Srivastava et al., 2014). On the contrary, some researchers found no effect on germination of false smut infected seeds (Seth, 1945; Kulkarni and Moniz, 1975). In addition, published reports indicate impact of the disease on seed quality attributes such as reduction in individual grain weights (Singh et al., 1992; Hegde and Anahosur, 2000; Srivastava et al., 2014). Abbas et al. (2014) showed that variation in germination of the disease contaminated seeds was specific to rice varieties. There has been no report on the effect of seed germination in the RFSm contaminated seeds in Bangladesh. Besides, there was no literature available on the quality of RFSm contaminated grains with respect to milling, physical, chemical and/or cooking properties (Nessa, 2017).

With the above background, this research was undertaken to investigate whether RFSm infected seeds affect seed and grain quality.

\section{MATERIALS AND METHODS}

\section{Seed germination}

Seeds of the variety BRRI dhan49 were collected during T. Aman harvesting period (late-October to mid-November) of 2014, 2015 and 2016 from the fields in experimental farm of the Bangladesh Rice Research Institute (BRRI), Gazipur, Bangladesh, located at $23^{\circ} 59^{\prime} \mathrm{N}$ latitude, $90^{\circ} 24^{\prime} \mathrm{E}$ longitude. This farm has built up as an intensive riceecosystem in the last 40 years by growing three rice crops annually in 192 fields spread over 40.48 hectare area (Nessa, 2017). Seeds were collected in two lots, contaminated with RFSm and clean, judged visually. Collected seeds were sundried for three days. The germination test was carried out in completely randomized design (CRD) using two treatments (RFSm contaminated seeds and clean seeds) in three replications. One petri dish served as one replication. Fifty seeds were placed in each petri dish on moist white germination paper previously soaked in sterile water. Petri dishes were placed (at $30^{\circ} \mathrm{C} \pm 2^{\circ} \mathrm{C}$ ) room temperature at $65 \%$ humidity for 14 days. All petri dishes were kept in with lid on for first three days of experimental period to enhance germination. On the fourth day the lids were removed. Sterile water was added to each petri dish as required to retain moisture. Seed germination was assessed visually, by count, every day and summed up for the experimental period. The germination percentage for each petri dish was calculated as follows:

Germination $(\%)=($ Number of seeds germinated in 14 days)/(Total number of seeds set for germination) $) \times 100$

\section{Grain quality evaluation}

The laboratory analysis for the seed quality evaluation was conducted at the Grain Quality and Nutrition (GQN) Division at BRRI headquarters at Gazipur, Bangladesh. Part of the samples of rough rice (unhusked paddy) of the test variety BRRI dhan49, clean and contaminated with RFSm, collected for seed germination test were used for grain quality evaluation. Samples were milled raw and analysed for physicochemical properties. The basic procedures of the analysis have been described by Dipti et al. (2003).

Milling characteristics. For milling outturn, $200 \mathrm{~g}$ rough rice (unhusked paddy) of each sample was dehulled by Satake rice mill. The resulting brown rice was polished (10\%) in Satake grain-testing mill TM05. Milled rice outturn was expressed as percent of milled rice. Head rice outturn was determined by separating broken rice manually and expressed as percent of head rice. 
Physical properties. Rough rice (unhusked paddy) length and breadth (mm), brown rice length and breadth $(\mathrm{mm})$, milled rice length and breadth $(\mathrm{mm})$ were measured by slide calliper. The length of milled rice was divided by its breadth to determine the length:breadth ratio. In determining the size, milled rice was classified into three classes: long $(>6 \mathrm{~mm})$, medium $(5-6 \mathrm{~mm})$ and short $(<5$ $\mathrm{mm}$ ) (Dipti et al. 2003). For shape, the length:breadth ratio of milled rice was grouped into three: slender (>3.0), bold (2.03.0) and short (>2.0) (Dipti et al. 2003). The appearance of the milled rice was ranked through visual observation. Chalkiness of kernel was visually scored for the presence of white belly, $\mathrm{Wb}$, (dorsal side of the grain) and degree of translucency. Four scale were used to classify the endosperm chalkiness of milled rice: $\operatorname{Tr}(0), \mathrm{Wb}_{1}(<10 \%), \mathrm{Wb}_{5}(10-20 \%), \mathrm{Wb}_{9}$ $(>20 \%)$. (Dipti et al. 2003). The brown rice colour was estimated visually.

Chemical properties. The polished rice was grounded by a Udy Cyclon sample mill for chemical analysis. Alakali Spreading Value (ASV) was estimated by dispersing triplicate six whole milled rice grains in $10 \mathrm{ml}$ $1.7 \%$ potassium hydroxide $(\mathrm{KOH})$ for $23 \mathrm{~h}$ at room temperature and scored according to Little et al. (1958). The five-scale classification for grouping ASV: High (1.0-3.0), Intermediate (4.0-5.0) and Low (6.0-7.0), values correspond to the gelatinization temperature. Amylose content (\%) was determined by the procedure of Juliano (1971). The five-scale classification was used to group amylase content of milled rice: Waxy (0-2\%), Very low (3-9\%), Low (10-19\%), Intermediate $(20-24 \%)$ and High ( $\geq 25 \%)$. Protein content was calculated from nitrogen and was determined by Micro Kjeldahl nitrogen, multiplied by a factor of 5.95 , based on $16.8 \%$ nitrogen contained in the major rice protein fraction gluten (Dipti et al., 2003).

Cooking properties. Cooking time was measured when $90 \%$ of cooked rice was totally gelatinized. Elongation ratio is the proportion of the length of cooked rice over the length of uncooked rice, measured by slide calliper. Imbibition ratio is the increase in volume of cooked rice over non cooked rice, measured by water displacement method (Dipti et al., 2003). Five gram of milled rice was placed in a graduated cylinder containing $50 \mathrm{ml}$ of water and the change in volume was noted. For cooked rice volume, $5 \mathrm{~g}$ of milled rice was cooked and the cooked rice was placed in the same cylinder and the change in volume was measured.

\section{Statistical analysis}

Data of seed germination and grain quality attributes, as appropriate, were analysed using single factor ANOVA to compare RFSm infected and uninfected (clean) seeds, and graphically presented the level of statistical significance. The results of seed germination were summarized as means of three replicates with their respected standard errors for each year of experimentation. The appropriate grain quality attributes were summarized as means of three years of evaluation with their respected standard errors.

\section{RESULTS}

\section{Seed germination}

The germination of clean seeds was $93 \pm 4 \%$, $72 \pm 3 \%$ and $80 \pm 2 \%$ ( \pm is standard error (SE)), in 2014, 2015 and 2016 T. Aman rice respectively (Fig. 1). The germination of corresponding visually identified RFSm contaminated seeds was lower, $89 \pm 3 \%$, $67 \pm 3 \%$ and $75 \pm 2 \%$, respectively. Across the three years, the germination of clean seeds was recorded as $82 \pm 4 \%$, compared to $77 \pm 4 \%$ with the RFSm contaminated seeds (Fig. 1); this difference was not significant at $95 \%$ probability level. 


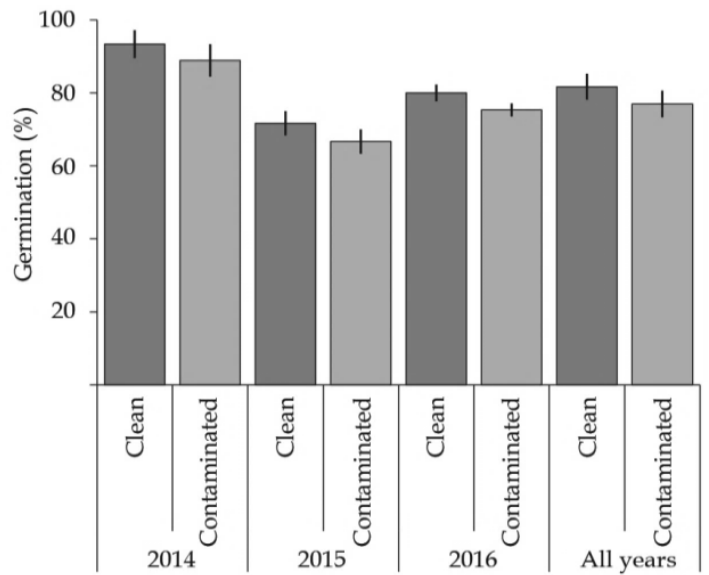

Fig. 1. Comparison of germination of false smut contaminated ('Contaminated') and uncontaminated ('Clean') field harvested seeds of 'BRRI dhan49' in 2014, 2015 and 2016 T. Aman rice season. Vertical bars represent standard errors.

\section{Seed quality}

On milling properties, as Table shows, the milling outturn in clean seeds was higher $(71.5 \pm 0.6 \%, \pm$ is standard error $(\mathrm{SE}))$ than RFSm contaminated seeds $(70.0 \pm 0.9 \%)$. A similar trend was observed in head rice yield $(68.9 \pm 0.9 \%$ in clean seeds versus $67.4 \pm 0.8 \%$ in RFSm contaminated seeds). With respect to physical properties, paddy (rough rice) length and breadth, brown and milled rice length and breadth were similar between the two sources of seeds (Table 1). Both seed types produced light coloured brown rice, and medium bold type grains after milling. The appearance of grains in both sources of seeds was rated as 'good', though the white belly and white center areas (attributes of chalkiness) were bigger in contaminated seeds compared to clean ones (Table 1).

Table 1. Comparison of quality attributes of false smut contaminated ('Contaminated') and uncontaminated ('Clean') field harvested seeds of BRRI dhan49 in 2014, 2015 and 2016 T. Aman seasons.

\begin{tabular}{|c|c|c|c|c|c|c|c|c|c|}
\hline \multirow{2}{*}{\multicolumn{2}{|c|}{ Attribute }} & \multicolumn{6}{|c|}{ Year and seed type } & \multirow{2}{*}{\multicolumn{2}{|c|}{$\begin{array}{c}\text { Pooled average } \\
\text { seed type }\end{array}$}} \\
\hline & & \multicolumn{2}{|c|}{2014} & \multicolumn{2}{|c|}{2015} & \multicolumn{2}{|c|}{2016} & & \\
\hline 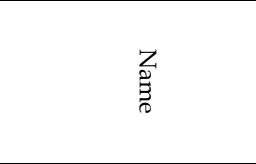 & 兂 & 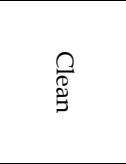 & 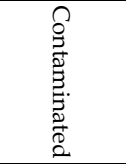 & $\begin{array}{l}\stackrel{\rho}{8} \\
\stackrel{\overbrace{}}{\mathscr{\Xi}}\end{array}$ & 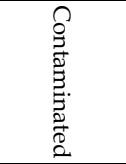 & $\begin{array}{l}\stackrel{2}{8} \\
\stackrel{8}{\xi}\end{array}$ & 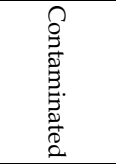 & 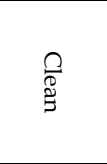 & 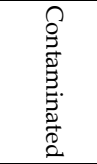 \\
\hline \multicolumn{10}{|l|}{ Milling properties } \\
\hline Milling outturn & $\%$ & 71.0 & 69.2 & 71.4 & 70.8 & 72.1 & 70.0 & $71.5 \pm 0.3$ & $70.0 \pm 0.5$ \\
\hline Head rice yield & $\%$ & 68.0 & 67.1 & 69.2 & 68.2 & 69.5 & 67.0 & $68.9 \pm 0.5$ & $67.4 \pm 0.4$ \\
\hline \multicolumn{10}{|l|}{ Physical properties } \\
\hline Paddy length & $\mathrm{mm}$ & 8.4 & 8.5 & 8.8 & 9.0 & 8.6 & 8.1 & $8.6 \pm 0.1$ & $8.5 \pm 0.3$ \\
\hline Paddy breadth & $\mathrm{mm}$ & 2.5 & 2.4 & 2.4 & 2.4 & 2.5 & 2.6 & $2.5 \pm 0.0$ & $2.5 \pm 0.1$ \\
\hline Brown rice length & $\mathrm{mm}$ & 6.1 & 6.1 & 6.2 & 6.3 & 6.0 & 6.0 & $6.1 \pm 0.1$ & $6.1 \pm 0.1$ \\
\hline Brown rice breadth & $\mathrm{mm}$ & 2.2 & 2.1 & 2.2 & 2.2 & 2.2 & 2.3 & $2.2 \pm 0.0$ & $2.2 \pm 0.1$ \\
\hline Brown rice colour & - & $\begin{array}{l}\text { Light } \\
\text { brown }\end{array}$ & $\begin{array}{l}\text { Light } \\
\text { brown }\end{array}$ & $\begin{array}{l}\text { Light } \\
\text { brown }\end{array}$ & $\begin{array}{l}\text { Light } \\
\text { brown }\end{array}$ & $\begin{array}{l}\text { Light } \\
\text { brown }\end{array}$ & $\begin{array}{l}\text { Light } \\
\text { brown }\end{array}$ & - & - \\
\hline Milled rice length (L) & $\mathrm{mm}$ & 5.5 & 5.5 & 5.6 & 5.6 & 5.6 & 5.0 & $5.6 \pm 0.0$ & $5.4 \pm 0.2$ \\
\hline Milled rice breadth(B) & $\mathrm{mm}$ & 2.1 & 2.1 & 2.0 & 2.1 & 2.1 & 2.1 & $2.1 \pm 0.0$ & $2.1 \pm 0.0$ \\
\hline $\mathrm{L} / \mathrm{B}$ ratio & - & 2.7 & 2.7 & 2.8 & 2.7 & 2.7 & 2.6 & $2.7 \pm 0.0$ & $2.7 \pm 0.0$ \\
\hline Size and shape & - & $\begin{array}{l}\text { Medium } \\
\text { bold }\end{array}$ & $\begin{array}{l}\text { Medium } \\
\text { bold }\end{array}$ & $\begin{array}{l}\text { Medium } \\
\text { bold }\end{array}$ & $\begin{array}{l}\text { Medium } \\
\text { bold }\end{array}$ & $\begin{array}{l}\text { Medium } \\
\text { bold }\end{array}$ & $\begin{array}{l}\text { Medium } \\
\text { bold }\end{array}$ & - & - \\
\hline Appearance§ & - & Good & Good & Good & Good & Good & Good & - & - \\
\hline Chalkiness & - & $\mathrm{Wb}_{1} / \mathrm{Wc}_{1}$ & $\mathrm{~Wb}_{5} / \mathrm{Wc}_{5}$ & $\mathrm{~Wb}_{1} / \mathrm{Wc}_{1}$ & $\mathrm{~Wb}_{5} / \mathrm{Wc}_{5}$ & $\mathrm{~Wb}_{9}$ & $\mathrm{~Wb}_{9}$ & - & - \\
\hline \multicolumn{10}{|l|}{ Chemical properties } \\
\hline Alkali spread value & Point & 5.3 & 5.3 & 5.8 & 6.4 & 3.9 & 4.3 & $5.0 \pm 0.6$ & $5.3 \pm 0.6$ \\
\hline Amylose & $\%$ & 24.7 & 24.0 & 24.5 & 24.0 & 24.2 & 24.0 & $24.5 \pm 0.1$ & $24.0 \pm 0.0$ \\
\hline Protein & $\%$ & 8.7 & 8.9 & 8.6 & 9.0 & - & - & $8.6 \pm 0.0$ & $9.0 \pm 0.0$ \\
\hline \multicolumn{10}{|l|}{ Cooking properties } \\
\hline Cooking time & Min & 20.0 & 15.3 & 20.0 & 16.3 & 15.3 & 16.0 & $18.4 \pm 1.6$ & $15.9 \pm 0.3$ \\
\hline Elongation ratio (ER) & - & 1.4 & 1.3 & 1.3 & 1.3 & 1.4 & 1.2 & $1.4 \pm 0.0$ & $1.3 \pm 0.0$ \\
\hline Imbibition ratio (IB) & - & 3.60 & 3.40 & 3.50 & 2.70 & 2.60 & 3.60 & $3.2 \pm 0.3$ & $3.2 \pm 0.3$ \\
\hline
\end{tabular}


Regarding chemical properties, the alkali spread value (ASV) was slightly bigger in contaminated seeds $(5.3 \pm 0.6)$ than clean seeds (5.0 \pm 0.6$)$. The amylose content was inferior in contaminated seeds $(24.0 \pm 0.0 \%)$ than clean seeds $(24.5 \pm 0.1)$. On the contrary, contaminated seeds had higher protein content $(9.0 \pm 0.0 \%)$ than clean seeds $(8.6 \pm 0.0 \%)$.

On cooking quality, clean seeds appeared to have higher elongation ratio $(1.4 \pm 0.0)$ than contaminated seeds $(1.3 \pm 0.0)$, whereas the imbibition ratio was similar (both and $3.2 \pm 0.3$ ) (Table 1). Results indicate that clean rice produced from contaminated seeds required less cooking time (15.9 \pm 0.3 minutes) than that from clean seeds (18.4 \pm 1.6 minutes).

Five of the studied grain quality attributes showed the level of statistical significance $\geq 90 \%$ on the difference between clean and RFSm contaminated seeds. The attributes are milling outturn (94\%), head rice yield $(93 \%)$, amylose content $(97 \%)$, protein content (95\%) and elongation ratio (90\%) (Fig. 2). The cooking time, explaining the difference between the two seed types, had the level of statistical significance of $82 \%$. The statistical difference for other attributes was not strong.

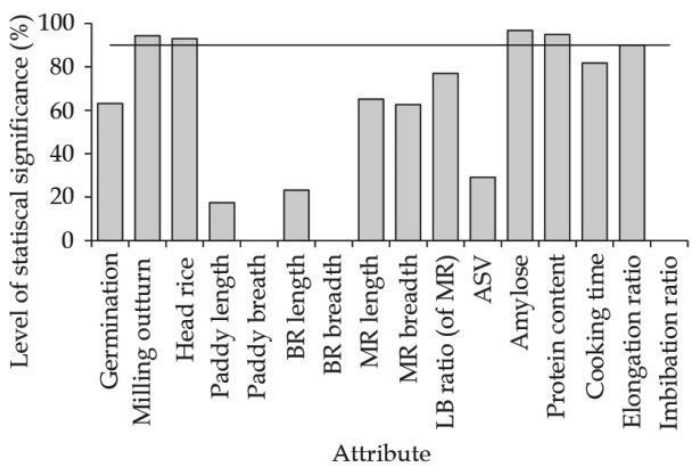

Fig. 2. Level of statistical significance of attributes related to seed quality of BRRI dhan 49 as affected by rice false smut disease in 2014, 2015 and 2016 T. Aman rice season. The horizontal line denotes for the demarcation of $90 \%$ level of statistical significance. BR is brown rice, MR is milled rice, $\mathrm{LB}$ is length-breadth and ASV is alkali spread value.

\section{DISCUSSION}

RFSm is a disease that directly affects the grains. It is established that smut balls produce mycotoxins known as ustiloxins (Koiso et al., 1992). Ustiloxins are cyclic peptides, which are toxic to plants and animals by interfering with microtubule function, thereby inhibiting mitosis (Koiso et al., 1994; Abbas et al., 2014). Scientists, thus, raised concerns on direct impact of RFSm on seed germination and grain quality. This study rightly addressed the issue given that information is seriously lacking under Bangladesh conditions. It has been overwhelmingly claimed that RFSm infected seeds have reduced germination ability as high as by $22-25 \%$ (Hegde and Anahosur, 2000; Sanghera et al. 2012). Other reports, however, show that such impact is much lower $(\sim 4 \%$ reduction as observed by Srivastava et al. 2014). This study, comprising three-year experimentation, recorded reduction in germination of RFSm contaminated seeds in the range of $4-5 \%$ compared to clean seeds; however, those differences were statistically insignificant $(\mathrm{P}>0.05)$. It has been proved that the fungusproduced ustiloxins inhibit seed germination (Abbas et al., 2000). The reported variations in literature on RFSm contaminated seed germination and in the present study may be related to the nature of seed contamination, and the type and quantity of ustiloxins that the pathogen produces. Rice has been reported to be more resistant to mycotoxins than the other major crops such as corn and wheat because its kernels develop and mature in a tightly closed protective husk (Abbas et al., 2000). Therefore, RFSm infected seeds (i.e. when spores residing on seed surface) are likely to be less affected in germination. Seth (1945) observed that seeds dusted with spores produced healthy plants. Besides, Takahashi et al. (2012) reported that false smut balls vary greatly in their 
production of ustiloxins ranging from none to large amounts of toxins. On the other hand, it has been stated that the amount and type of toxins produced by false smut balls varies greatly depending on geographical and environmental conditions (Abbas et al., 2014). This group of scientists have proved that some rice varieties had non-response to seed germination at lower level of ustiloxins $(1000 \mu \mathrm{g} / \mathrm{ml}$ rice false smut gall cell-free extract), whereas had high response with 10 times higher dose. It is then likely that nature of seed contamination in the experimental site of the study area was either 'seed infection type' and/or in the case of 'seedinfestation' (i.e. when spores residing inside seed surface), the environment and/or pathotype had the inherent capacity of producing low toxins. Findings of this study, thus, have opened a new window for future research in this direction.

There has been extremely limited information worldwide whether RFSm related seed contamination affects the attributes of seed quality (Nessa, 2017). This study shows there was a tendency of inferior milling properties (milling outturn and head rice yield) with RFSm contaminated grains, but statistically they were similar to clean grains. The physical properties did not deteriorate in contaminated grains. With respect to chemical properties, alkali spread value and protein content tended to be higher in RFSm contaminated grains. The protein content of the clean seeds as recorded in the study as the test variety was similar to what has been reported by Shozib et al. (2017). The seed contamination significantly reduced the amylase content, but surprisingly increased protein content. Interestingly, rice grains derived from contaminated seeds reduced cooking time compared to grains from clean seeds; this difference was, however, statistically insignificant $(\mathrm{P}>0.05)$. Taken all together, this study has made the first step in highlighting seed quality issues in relation to rice false smut disease.

It has been reported that RFSm contaminates rice grain and straw to potentially cause human or animal poisoning (Li et al., 1995). However, Abbas et al. (2014) find under southern USA context that RFSm does not produce detectable ustiloxins; and it affects the appearance, but not the food safety of rice in the United States. While no such experiments conducted under this study, it was revealed that people in the countryside of Bangladesh were eating smut balls as raw or as popped-rice (Nessa, 2017). Also, Nessa (2017) observed that insects were very much attracted to smut balls.

\section{CONCLUSIONS}

This study provides indication of inferior milling outturn and head rice yield, reduced amylose content and increased protein content in RFSm contaminated seeds. It also shows a tendency in reduced seed germination, and less cooking time required from such contamination. Future research is needed to fully establish those causations. Besides, investigation is also needed to identify the kinds and quantity of toxins produced by the smut balls under Bangladesh condition to address the food safety issue, if any, in relation to the disease.

\section{ACKNOWLEDGEMENTS}

This study has a part of the senior author's $\mathrm{PhD}$ research. The Bangladesh Agricultural Research Council (BARC) offered a PhD fellowship, and the Bangladesh Rice Research Institute (BRRI) granted study leave and provided with research facilities to run the $\mathrm{PhD}$ programme- the senior author deeply acknowledges both BARC and BRRI for that. 


\section{REFERENCES}

Abbas, H K, R D Cartwright, G L Windham, W Xie, W T Shier and C J Mirocha. 2000. The Presence of mycotoxins and fungi in rice and corn in the southern United States. Bulletin of the Institute for Comprehensive Agricultural Sciences Kinki University. 8:23-28.

Abbas, H K, W T Shier, R D Cartwright and G L Sciumbato. 2014. Ustilaginoidea virens infection of rice in Arkansas: toxicity of false smut galls their extracts and the ustiloxin fraction. Am. J. Plant Sci. 5: 3166-3176.

Atia, M M M. 2004. Rice false smut (Ustilaginoidea virens) in Egypt. J. Plant Dis. Protection. 111: 71-82.

Dhaka Tribune. 2013: Jhenaidah farmers worried over smutty rice. In: Dhaka Tribune on 4 November 2013 (http://www.dhakatribune.com /agriculture/2013/nov/04/jhenaidah-farmersworried-over-smutty-rice). Accessed 2015 January 14.

Dipti, S S, M N Bari and K A Kabir. 2003. Grain quality characteristics of some Beruin rice varieties of Bangladesh. Pakistan J. Nutri. 2: 242-245.

Hegde, Y and K H Anahosur. 2000. Effect of false smut of rice on yield components and growth parameters. Indian Phytopathol. 53: 181-184.

$\mathrm{Hu}, \mathrm{D}$ J. 1985. Damage of false smut to rice and effect of the spores of Ustilaginoidea virens on germination of rice seeds. Zhejiang Agric. Sci. 4: 164-167.

Juliano, B O. 1971. A simplified assay for milled rice amylase. Cereal Sci. Today. 16: 334-338.

Kabir, M S, M U Salam, A Chowdhury, N M F Rahman, K M Iftekharuddin, M S Rahman, M H Rashid, S S Dipti, A Islam, M A Latif, A K M S Islam, M M Hossain, B Nessa, M A Ali and J K Biswas. 2015. Rice Vision for Bangladesh: 2050 and Beyond. Bangladesh Rice J. 19 (2): 1-18.

Koiso, Y, M Natori, S Iwasaki, S Sato, R Sonoda, R Fujita, H Yaegashi and Z Sato. 1992. Ustiloxin: A Phytotoxin and a Mycotoxin from False Smut Balls on Rice Panicles. Tetrahedron Letters. 33: 4157-4160.

Koiso, Y, Y Li, S Iwasaki, K Hanaoka, T Kobayash, R Sonoda, Y Fujita, H Yabgashi, Z Sato. 1994. Ustiloxins, Antimitotic cyclic peptides from false smut balls on rice panicles caused by Ustilaginoidea virens. J. Anti. 47: 765-773.

Kulkarni, C S and L Moniz. 1975. False smut of rice - an airborne disease. Current Science. 44: 483-484.

Li, W, L Li, A Feng, X Zhu and J Li. 2013. Rice false smut fungus, Ustilaginoidea virens, inhibits pollen germination and degrades the integuments of rice ovule. Am. J. Plant Sci. 4: 2295-2304.

Little, R R, G B Hinder and E H Dawson. 1958. Differential effect of dilute alkali on 25 varieties of milled white rice. Cereal Chemistry, 35: 111-126.

Nessa, B. 2017. Rice False Smut Disease in Bangladesh: Epidemiology, Yield Loss and Management.
PhD thesis, Department of Plant Pathology and Seed Science, Sylhet Agricultural University, Sylhet, Bangladesh.

Nessa, B, M U Salam, A H M M Haque, J K Biswas, W J MacLeod, M A Ali, K P Halder and J Galloway. 2015. FLYER: A simple yet robust model for estimating yield loss from rice false smut disease (Ustilaginoidea virens). Am. J. Agric. Biol. Sci. 10 (1): 41 - 54.

Nessa, B, M U Salam, A H M M Haque, J K Biswas, Q S A Jahan, M A I Khan, M R Bhuiyan, A Ara, M R Munir, J Galloway, M S Kabir and M A Ali. 2016. Density and distribution of false smut balls on infected rice panicles. Bangladesh Rice J. 20 (2): 73-79.

Sanghera, G S, M A Ahanger, S C Kashyap, Z A Bhat, A G Rather and G A Parray. 2012. False smut of rice (Ustilaginoidea virens) under temperate agroclimatic conditions of Kashmir, India. Elixir Bio Tech. 49: 9827-9830.

Sarker, M M, A H M M Haque, B Nessa, M U Salam, M M Islam and A Muqit. 2016. Status of rice false smut disease in Natore district of Bangladesh. Bangladesh Rice J. 20 (2): 31-37.

Seth, L N. 1945. Studies on the false-smut disease of Paddy caused by Ustilaginoidea virens (Cke.) Tak. Indian J. Agric. Sci. 15: 53-55.

Shozib, H B , M M Hossain, S Jahan, M S Alam, S C Das, S Alam, R B Amin, M M Hasan, R Malo, M R Islam, H U Shekhar and M A Siddiquee. 2017. Study of biochemical and cooking quality traits of major rice varieties of Bangladesh. Malays. Appl. Biol. 46 (4): 55-62.

Singh, S, V Pal and MS Panwar. 1992. False smut of rice its impact on yield components. Crop Research (Hisar). 5: 246-248.

Srivastava, J P, D K Maurya and G D Kushwaha. 2014. Effect of false smut (Ustilaginoidea virens) on seed yield and quality attributes in rice varieties. Agric. Biol. Res. 30: 196-200.

Takahashi, M, T Ashizawa, N Yamanaka, M Arai and Y Takahashi. 2012. Pathogenic isolates of Ustilaginoidea virens differ greatly in their production of ustiloxin in a rice false smut balls. Japanese J. Phytopathol. 78: 305-308.

Upadhyay, A L and R V Singh. 2013. Yield loss assessment in rice due to false smut. Annals of Plant and Soil Res. 15: 173-174.

Webster, R K and P S Gunnell. 1992. Compendium of Rice Diseases. American Phytopathol. Society, St. Paul, Minnesota, USA.

Zhang, Y, K Zhang, A Fang, Y Han, J Yang, M Xue, J Bao, D $\mathrm{Hu}, \mathrm{B}$ Zhou, X Sun, S Li, M Wen, N Yao, L-J Ma, Y Liu, M Zhang, F Huang, C Luo, L Zhou, J Li, Z Chen, J Miao, S Wang, J Lai, J-R Xu, T Hsiang, Y-L Peng, W Sun. 2014. Specific adaptation of Ustilaginoidea virens in occupying host florets revealed by comparative and functional genomics. Nature Communications 53849. 
